\title{
XIII
}

\section{Interiority and Intersubjectivity in Dostoevsky: The Vasya Shumkov Paradigm}

\author{
Yuri Corrigan
}

\section{Indwelling Self/Relational Self}

Among studies of Dostoevsky's conception of personality, two largely incompatible and equally influential schools of thought can be discerned. On the one hand, Dostoevsky has been read as a neo-Romantic "expressivist" who situated the roots of the personality, and of the world itself, in the inexhaustible depths of the "human soul."' The elder Zosima's teaching in The Brothers Karamazov on the organic nature of the personality whose roots "touch other worlds" provides a vivid illustration of this view: Zosima describes our "secret innermost sensation" of a "connection with ... a celestial and higher world," and our sense that "the roots of our thoughts and feelings are not here, but in those other worlds" (PSS, 14:291). ${ }^{2}$ It was in this mystical Romantic vein that Vladimir Solovyov

1 By "expressivist," I mean the view that the human personality is an expression of the sources of nature that lie in its depths. For Charles Taylor's espousal of the term "expressivism," see "The Expressivist Turn," in Sources of the Self: The Making of Modern Identity (Cambridge, MA: Harvard University Press, 1989), 368-92. On Dostoevsky and expressivism, see Malcolm V. Jones, Dostoyevsky after Bakhtin (Cambridge: Cambridge University Press, 1990), 3.

2 F. M. Dostoevskii, Polnoe sobranie sochinenii v tridtsati tomakh [PSS], ed. V. G. Bazanov et al. (Leningrad: Nauka, 1972-90); hereafter cited as PSS by volume and page. All translations are mine. 
spoke of Dostoevsky's belief in "the divine power in the soul" and in its "divine origin." 3 The personality, understood thus, becomes not only a repository for divinity but also an "all-encompassing," "microcosmic" universe within itself. ${ }^{4}$ Various traditions of selfhood stand behind this notion of personality, among them the Neoplatonic Augustinian self that turns inward to discover the presence of the divine in its depths, or the German Romantic self that reaches, in its dark inscrutable basis, into the very sources of nature and of the universe. ${ }^{5}$

In observing the radically social, relational nature of Dostoevsky's characters, however, readers have questioned whether this apparent belief in the infinite inward capaciousness of the self extends to his active psychological portraits. ${ }^{6}$ Thus, a second school of thought finds its center in what can be described as Bakhtin's Dostoevsky: a remarkably contemporary, potentially postmodern writer who reconceived traditional notions of self in intersubjective dialogical space. This is the Dostoevsky who, according to Tzvetan Todorov, "rejects an essentialist conception of man," and locates the "psychic structure" of the personality entirely in human relationships, and for whom "the human being has no existence prior to the other or independent of him." ${ }^{\prime}$ Bakhtin called attention to the absence of a psychologized

3 Vladimir Solovyov, Sobranie sochinenii Vladimira Sergeevicha Solov'eva (St. Petersburg: Knigoizdatel'skoe Tovarishchestvo "Prosveshchenie," 1914), 3:185.

4 Dmitrii Chizhevskii, "Dostoevskij-psikholog," in O Dostoevskom: Sbornik statej (Prague, 1929), 1:55.

5 "If everything in nature is living, and if we ourselves are simply its most self-conscious representatives, the function of the artist is to delve within himself, and above all to delve within the dark and unconscious forces which move within him, and to bring these to consciousness by the most agonizing and violent internal struggle. This is Schelling's doctrine"; Isaiah Berlin, The Roots of Romanticism (Princeton, NJ: Princeton University Press, 1999), 98.

6 Edith Clowes articulates some of this ambivalence when, after having compared Dostoevsky to Nietzsche as a proponent of the Romantic emphasis on integrating the subliminal natural forces that undergird consciousness, she nevertheless point out that "Dostoevsky's moral consciousness is much more socially oriented than Nietzsche's" and that Dostoevsky is less interested in "penetrating the complex interactions of subliminal forces in the intrapersonal sphere" and more focused on "resolution of conflicts ... in the interpersonal sphere"; Clowes, "Self-Laceration and Resentment: The Terms of Moral Psychology in Dostoevsky and Nietzsche," in Freedom and Responsibility in Russian Literature: Essays in Honor of Robert Louis Jackson (Evanston, IL: Northwestern University Press, 1995), 133.

7 Tzvetan Todorov, "Notes from the Underground," in Genres in Discourse (Cambridge: Cambridge University Press, 1990), 89. Todorov, echoing Bakhtin, asserts that 
and naturalized sense of self in Dostoevsky's characters, who lack the detailed interiority or personal biography of realist literature, and whose radical inner formlessness abates only in the activity of interpersonal dialogue. ${ }^{8}$ These characters, Bakhtin observed, are always on the "threshold," looking outward, existing fully in the "living present," never determined or limited by unconscious lives or biographical pasts. ${ }^{9}$ Bakhtin's perspective helps illuminate the relational nature of personhood in Dostoevsky, whose characters apprehend their depths outside of themselves, "in the souls of others." From this perspective, if the self is rooted in other worlds, as Zosima espouses, then those other worlds are not transcendent essences but rather the worlds of other personalities.

Thus, the self in Dostoevsky is thought of, on the one hand, as an essence, a bottomless depth, encompassing and expressing the entire universe, and, on the other hand, as an activity, event, or point of view that constitutes itself outwardly through relationships. My present treatment here engages this

Dostoevsky locates "the essence of being in the other" (87). For a similar view, see also Julia Kristeva, "The Ruin of a Poetics," in Russian Formalism: A Collection of Articles and Texts in Translation, ed. Stephen Bann and John E. Bowlt (Harper and Row, 1973), $102-21$.

8 Malcolm Jones accepts "expressivism" as an important aspect of Dostoevsky's philosophical outlook and argues, interestingly, that the "fantastic realism" of a Bakhtinian Dostoevsky is "not to be located in the process of spiritual evolution described by Dostoyevsky ... but in the 'deviations,' ... the destabilizing effects of what Bakhtin calls heteroglossia in urban life where man is torn from his roots" (Dostoevsky after Bakhtin, 6-7).

9 Bakhtin, Problems of Dostoevsky's Poetics, ed. and trans. Caryl Emerson (Minneapolis: University of Minnesota Press, 1984), 108. See Irina Sandomirskaia's forceful critique of Bakhtin's concept of the self: "A body without a name, without a personality and without borders - such is the subject in the inhuman political economy that goes by the name of dialogue"; Sandomirskaia, "Golaia zhizn', zloi Bakhtin i vezhlivyi Vaginov: Tragediia bez khora i avtora," in Telling Forms: 30 Essays in Honour of Peter Alberg Jensen, ed. Karin Grelz and Susanna Witt (Stockholm: Almqvist \& Wiksell, 2004), 338.

10 Bakhtin, Problems of Dostoevsky's Poetics, 61; emphasis in original. See Holquist's discussion of Bakhtin's move against "untrammeled subjectivity," the "old conviction that the individual subject is the seat of certainty, whether the subject so conceived was God, the soul, the author, or my self" (19); see Michael Holquist, Dialogism: Bakhtin and His World, 2nd ed. (New York: Routledge, 2002), esp. 14-27. For an example of Bakhtin's resonance in the fields of psychology and cultural theory as a thinker who "challenges the idea of a core, essential self," see Hubert J. M. Hermans, "The Dialogical Self: Toward a Theory of Personal and Cultural Positioning," Culture and Psychology 7, no. 3 (2001): 243-81. 
duality in commentary by examining the tension between interiority and intersubjectivity already distinctly evident in one of Dostoevsky's much-neglected early stories, "A Weak Heart" ("Slaboe serdtse"), published in 1848. Both the indwelling and relational models of selfhood are evoked in this portrait of how two personalities of significant interior complexity unravel themselves in external, intersubjective space. I shall focus on the paradigm of the collapse of the collective, intersubjective personality in "A Weak Heart" as a window into Dostoevsky's career-long meditation on the problem of personal essence (or soul). In using the early story as point of entry into Dostoevsky's expansive meditation of the self, I shall also explore "A Weak Heart" as a blueprint for the portrait of collapsed interiority in Crime and Punishment.

\section{Intimate Friendship and the Collective Self}

"A Weak Heart" depicts the anxious travails and gradual descent into madness of one Vasya Shumkov, a humble, ardent, slightly disfigured clerk who has been entrusted with a large amount of copying work by his superior and benefactor, Yulian Mastakovich. Because of a newly formed engagement with his beloved Liza, whom he has fervently pursued for weeks, Vasya has egregiously neglected his work. His roommate and best friend, Arkady Nefedevich, tries to help him finish the copying, attempting at all costs to shore up his friend's sanity, but Vasya, overwhelmed by the emotions of his newfound happiness, and tormented by his "ingratitude" before his benefactor, whom he feels he has betrayed, is ultimately beyond saving. Vasya undergoes a pitiful public collapse, is removed to an asylum, and Arkady is left alone without his friend in the cold and ghostlike city of St. Petersburg.

The work has been consistently read, for good reason, as "a story of social protest" in its illustration of how a lowly civil servant is crushed by the hierarchical rank-and-file nature of imperial Russia. ${ }^{11}$ According to this traditional reading,

11 Victor Terras, The Young Dostoevsky (1846-49) (The Hague: Mouton, 1969), 39. See also W. J. Leatherbarrow, "Idealism and Utopian Socialism in Dostoyevsky's Gospodin Prokharchin and Slaboye serdtse," Slavonic and East European Review 58, no. 4 (1980): 524-40; and Joseph Frank, Dostoevsky: The Seeds of Revolt, 1821-1849 (Princeton, NJ: Princeton University Press, 1979), 318-22. Donald Fanger avoids the political context, characterizing Vasya as prototype for "the generous dreamer" who "cannot stand the anomalous burden of happiness in an imperfect world"; see Fanger, Dostoevsky and Romantic Realism: A Study of Dostoevsky in Relation to Balzac, Dickens, and Gogol (Evanston, IL: Northwestern University Press, 1998), 168. 
the meek Vasya Shumkov, in his wrenching psychological collapse, is a representative of Dostoevsky's "downtrodden" (the focus of his early, socially oriented writing), his breakdown the result of his having utterly internalized his subordinate status. ${ }^{12}$

When read in the context of Dostoevsky's extended inquiry into the notion of relational personhood, however, the passionate, intimate attachment between Vasya and his roommate, Arkady, seems less a facet of Dostoevsky's social commentary and more the kernel of a larger philosophical and psychological project. The loving friendship vividly expresses the dangers of intimacy in Dostoevsky's world, as the friends' closeness leads directly to the replacement of aspects of the self with the activities of the other. In this sense, the relationship provides a concept of intersubjective selfhood notably different from, and considerably more pathological than, the dialogical model espoused by Bakhtin: in Vasya and Arkady we see an overwhelming need for the other as a completion of one's own unfinished personality, a personality that degenerates as it becomes gradually subsumed and supplanted by its loving but overpowering counterpart. As we shall see, Vasya's escape from assimilation by Arkady's personality prefigures numerous scenes and paradigms from the later works in which characters struggle to be released from their imprisonment within intersubjective personalities, while encountering within themselves a lack of architecture, an atrophied self, propped up and supplemented by the tireless activity of another person.

The friendship between Arkady and Vasya enacts a complementary distribution of faculties between adjacent personalities, of a vigilant administrative mind (Arkady) that binds itself to a subordinate, largely irrational, intensely feeling, obedient nature, or "weak heart" (Vasya). Arkady plays the role of the friends' collective superego, having "loved [Vasya] so, watched over him, instructed him at every step with saving advices" (PSS, 2:28). As Vasya's external conscience, he takes on full responsibility for his friend's work deadline, beseeching Vasya to look to him for guidance, to "hold to me," as he puts it, so that "I will stand over you with a stick today and tomorrow, and all night, and I will torment you in your work: finish up! Finish up faster, brother!” (2:29). Arkady's zealous solicitude often resembles an invasion, or annexation, of his friend's agency. He consistently bemoans the fact that he cannot take over for Vasya entirely, that he cannot save

12 See N. A.Dobroliubov, “Zabitye liudi," in Literaturno-kriticheskie stat'i (Moscow, 1937), 480-81. 
his friend by simply occupying his place: "How annoying that I cannot help you," he exclaims to Vasya, "or else I would have taken it and would have written it all for you ... Why don't you and I have the same handwriting?” (2:29). Arkady constantly expresses the desire to substitute himself for Vasya, stressing, for example, his ability to sign Vasya's name: "I sign your name terribly similarly and make the same curl ... Who would notice!" (2:31). Vasya, in turn, apparently conceives of his own existence as directly dependent on Arkady's, and he continually declares, rather mysteriously, that he "would not be living in this world" were it not for his love for Arkady $(2: 18,26)$. The weaker of the two men, Vasya is generally inclined to accept Arkady's administration, looking at his friend "ever so timidly ... as if his decision ... depended on him" (2:22), his pathetic "feeble" (2:17) physicality repeatedly overwhelmed by Arkady's "leonine," (2:22) "powerful greedy ... embraces" (2:33) and "strong arms" (2:17).

As co-joined personalities, Arkady and Vasya exhibit an extreme degree of intimacy. They constantly throw themselves into each other's ardent, loving embraces (PSS, 2:17, 18, 36, 42, 44, 47). Early in the story, Arkady lifts Vasya up and carries him around the room like a child, "pretending that he was lulling him to sleep" (2:17). ${ }^{13}$ Later on, "Arkady thr[ows] himself upon him, like a mother whose kindred child is being taken away" (2:44). At times, the friends are so intimately connected that they appear to share a nervous system: "Vasya held him by the shoulders, looked into his eyes and moved his lips as if he wanted himself to say the words for him" (2:22). Their intimacy, moreover, extends beyond the physical. Arkady claims to have special insight into Vasya's inner processes- "I understand you; I know what is happening within you" (2:37) — and Vasya wonders at his friend's uncanny powers of perception: "For a long time now I've wanted to ask you: how is it that you know me so well?" (2:39).

Like Ivan and Smerdyakov in Brothers Karamazov, Arkady sees Vasya's actions as realizations of his own private intentions. At first surprised by Vasya's decision to get married, he then recalls the impulse in himself: "I myself, brother, thought about getting married; and now suddenly you're getting married, so it's all the same" (PSS, 2:19). He then quite suddenly discovers in himself the same passionate love for the same woman (he "was in love, fatally in

13 Katherine Strelsky has suggested "feminine identification resulting in homosexual panic" as the real reason for Vasya's demise; Strelsky, "Dostoevsky's Early Tale, 'A Faint Heart," Russian Review 30, no. 2 (1971): 148. 
love with Liza"): "Just as she looks after you, let her look after me too. Yes, friendship for you and friendship for her; you are indivisible now; only I will have two beings like you instead of one" (2:29); to which Vasya, "terribly pleased" with Arkady's plan to invade his marriage, "pointed out that this was just how it should be and that now they will be even greater friends" (2:28-29). For her part, Vasya's fiancée intuitively understands the bizarre fluidity between the friends' identities when she cries out, "in the most naïve rapture," her hope for the future: "We will be the three of us like one person!" $(2: 28)$.

In this portrait of intimate friendship, we encounter another curious detail: the two heroes, utterly preoccupied with their shared concerns over Vasya's predicament, have no tangible pasts, except for some intentionally obscured details - for example, that they are both orphans, and that Vasya, unlike Arkady, is initially presented without patronymic, a detail the author promises to explain but then never does. Concerning Arkady's past, the narrator promises to recount an episode-"once it even happened that ... But this can wait until later" (PSS, 2:26) — and again conspicuously fails to deliver on his promise. These references to the past, appearing as obvious ellipses in the text, emphasize a lack within these characters, a blank space where memory or personal biography fails to reside. Indeed, their personalities appear to be unfolded entirely in their intense mutual interactions.

The intimate relationship of extension into the other evidently recalls elements of the doppelgänger tradition, and in fact replays many of the scenes from Dostoevsky's The Double, which was published two years earlier: we think of Golyadkin Senior when Arkady rushes through the streets of St. Petersburg, trying to anticipate and preemptively reverse the self-destructive behavior of his counterpart; or when he suddenly runs into the guilty Vasya, "nose to nose," like Golyadkin with his double on the street, and Vasya stops "like one caught in a crime" (PSS, 2:35); or especially in the public scandal at the end, when Vasya appears before his superiors in a deluded, incoherent, and trembling state and, like Golyadkin, is removed to an asylum. The story represents a departure from The Double, however, in that, unlike Golyadkin, who encounters a perfect replica of himself, Arkady and Vasya are unmistakably two separate individuals. Here Dostoevsky emphasizes his growing interest not in one personality that projects itself onto the outside world, externally dramatizing its own self-consciousness, but in the psychology of two discrete, sovereign individuals who come to enact the behavior of a single self. 


\section{Pretending to Sleep: Escape from the Other}

As mentioned above, the story dramatizes a crisis in the friendship, in which Vasya, because of some nascent and concealed inner anguish, begins to refuse Arkady's administrative instructions. We discover that Vasya, by the time the story begins, has recently begun nurturing a sense of interior privacy. Just as he keeps the shameful secret of his neglected, unfinished work- "five of the thickest notebooks" (PSS, 2:37) — hidden from Arkady in a box, he has told Arkady nothing of his engagement to Liza, and when Arkady teasingly holds his friend down, trying to force the confession out of him, Vasya insists on the dignity of his personal interior space, exclaiming that "if you had gone on to ask me 'what's her name?' I swear I'd have killed myself before answering you” (2:18). Vasya's secrecy is symptomatic of a larger transformation in his character, a change that he himself does not understand. He tries to explain his newfound inner complexity to Arkady, vaguely describing a growing consciousness of himself as separate from others, with an attendant longing for dignity and responsibility:

"It seems to me that I didn't know myself before ... and I only discovered others yesterday too. I ... didn't feel, didn't value fully. The heart ... in me was callous.... Listen, how did it happen that I hadn't done any good to anyone on the earth, because I was incapable,... And so many have done good to me! Take you first: do you think I don't see. I was ... only keeping quiet!” (PSS, 2:39)

The experience of being loved and recognized by his fiancée has evidently shaken Vasya, forcing him to evaluate himself as a discrete personality. "I am undeserving of this happiness!" he protests to Arkady, "what have I done that was special, tell me! ... And I! Such a woman loves me, me ... as I am” (2:25). Thus, a distinct moral ambiguity accompanies the emergence of interior secrecy, since it is connected, on the one hand, with the discovery of self-worth at being loved and, on the other hand, with the subliminal criminal secrets of the neglected work and the hidden notebooks.

Arkady perceives danger in his friend's emergent complexity. He beseeches Vasya to "reveal [his concealed] torments" so that he can take responsibility upon himself. He repeatedly offers to act as intermediary between Vasya and his "benefactor," Vasya's section head, Yulian Mastakovich, who is, to Vasya, a divine, omnipotent being. "I'll save you!" he offers to Vasya, "I'll go to Yulian Mastakovich ... don't shake your head, no, listen! ... I'll explain ... how you're destroyed, how 
you're tormenting yourself. ... I'll sacrifice myself for you ... don't contradict me!" (PSS, 2:38). Vasya, however, is determined to free himself from Arkady's government. Faced with Arkady's intention to take his place, he "cries out, turns white as a wall," and protests vehemently: "Do you know that you're killing me right now?" (2:37). He is especially anxious about Arkady's helpful plan to sign Yulian Mastakovich's visitors' books for him (in other words, to subsume his identity), afraid that his benefactor will notice "that it's a different hand" (2:31). In Arkady's presence, he accepts his orders docilely and agrees to stay home to copy the neglected work. When Arkady leaves, however, Vasya's agency awakens. As Arkady rushes to the benefactor's residence to sign, he notices that Vasya has secretly escaped to sign his own name- "imagine his surprise when before him appeared Vasya Shumkov's very own signature!" (2:35) —Vasya's gesture, as it were, of insistence upon his own unannexable personality. Thus, the awakening of the self is portrayed through these irrepressible desires in Vasya: to sign one's own name, to atone for one's crimes, to feel the full weight of one's "guilt" before "God," to repent and to pray for divine mercy, to "tell him myself," to "go myself": "I'll explain everything myself ... he'll see my tears, he'll be moved by them" (2:38-40).

The story provides us with a clear vantage point onto one of Dostoevsky's most ubiquitous leitmotifs of the emergence and concealment of interiority (and thus of the instability of the intersubjective self): the action of pretending to sleep. In Arkady's dream, he sits over a sleeping Vasya, symbolically enacting the structure of their relationship, with Arkady as a vigilant consciousness to Vasya's supine, malleable, unconscious body. The dream — an important moment in Dostoevsky's early conception of the collective personality_dramatizes Vasya's transformation:

\footnotetext{
It seemed that he [Arkady] was not sleeping and that Vasya, as before, was lying on the bed. But the strangest thing! It seems Vasya is pretending, that he is even deceiving Arkady and is now getting up ever so quietly, observing him out of the corner of his eye and stealing to the desk. A burning pain seizes Arkady's heart; it was vexing, sad and difficult to see that Vasya doesn't trust him, that he's hiding and concealing from him. He wanted to grab him, to cry out and carry him to the bed ... Then Vasya screamed out in his arms, and Arkady was carrying a lifeless corpse to the bed. (PSS, 2:43)
}

The events of the dream vividly portray Vasya's attempt to emancipate himself from Arkady's will, to overcome his role as the passive, sleeping body to Arkady's administrative mind. Still pretending to be subdued, he has secretly 
awakened to his own agency, and Arkady attempts to seize control of his friend, to force him into unconsciousness, even by destroying him — reducing him to a "lifeless corpse"-in the process. This image of pretend sleep, as a motif of the unstable intersubjective self, extends throughout Dostoevsky's writing-for example in The Demons, in Stepan Trofimovich's attempt to escape Varvara Petrovna's vigilant administration (PSS, 10:502) or in Maria Timofeevna's flight from Stavrogin (10:219), and later, in Smerdiakov's murderous pretend sleep in Brothers Karamazov, which dramatizes all too literally Ivan's submerged, suppressed intention.

\section{Self without Soul}

The story's final passage-in which Arkady, lamenting his friend's demise, experiences a vision of an unearthly St. Petersburg, as though "a new city were taking shape in the air"-presents a fascinating description of the severed collective self. The episode has received a great deal more commentary than the rest of the story, as an autobiographically derived epiphany that Dostoevsky extracted from the story thirteen years later and inserted into a journalistic feuilleton. ${ }^{14}$ Because Dostoevsky himself tore the passage from its original context, criticism has followed and has weighed it on its own merits. Readers have argued that Arkady's glimpse into "the fantastical, magical reverie" of the city "that will disappear in its turn and waft into steam to the dark blue sky" (PSS, 2:47-48) is an early presentiment of Dostoevsky's program of "fantastic realism," of his separation from quotidian, earthly reality and his discovery of another, spiritual realm. ${ }^{15}$ In treating Arkady's experience as a form of mystical initiation into an otherworldly realm, however, readers overlook the implicit emphasis upon Arkady's bereaved status, since he encounters this vision of a second, disembodied, ethereal city in the air after an element of his personality has collapsed and vanished.

14 Arkady's vision is repeated almost verbatim, now from the first person, in Dostoevsky's 1861 "Peterburgskoe snovidenie v stikhakh i proze" (PSS, 19:67-85).

15 See, for example, Fyodor Stepun, Vstrechi (Munich: Tovarishchestvo zarubezhnykh pisatelei, 1962), 15; and Fanger, Dostoevsky and Romantic Realism, 168. Bakhtin reads the vision as a "carnivalized sense of Petersburg" (180n), a way of placing the city itself "on the threshold" so that it too, like Dostoevsky's personalities, is "devoid of any internal grounds for justifiable stabilization." Bakhtin, Problems of Dostoevsky's Poetics, 167. 
Perhaps as a result of reading the scene outside of its narrative context, critics consistently gloss over the strangest part of the passage-the peculiar physiological reaction that Arkady suffers as he looks out over the Neva. We are told that he experiences a sudden insight into Vasya's experience and shudders, feeling "the surge of some powerful and hitherto unknown sensation" as a "spring of blood" fills his "heart":

Some kind of strange thought visited the orphaned comrade of poor Vasya. He gave a start, and his heart was as if filled in this moment with a hot spring of blood, which suddenly boiled up from the surging of some powerful sensation, hitherto unknown to him. It was as if he only now ... discovered why his poor Vasya, who had not been able to bear his happiness, had lost his mind. His lips quivered, his eyes blazed, he grew pale, and it was as if his eyes were opened to something new in this moment. (PSS, 2:48)

The bizarre description suggests that, in the absence of Vasya as cathexis, as externalized bearer of his suppressed emotional life, Arkady painfully feels the upsurge of the atrophied faculties within himself that had formerly been replaced externally by his friend's activity. Vasya too, when he attempted to escape Arkady's protection, felt stricken and overwhelmed by the new burden of thought that the absence of Arkady awakened in him, a sensation he experienced physically: "He ran his hand over his forehead as if wanting to remove from himself some kind of heavy, oppressive weight that had lain on his entire being" (PSS, 2:43). Arkady's vision on the Neva in this context can be seen as a depiction of the anguish of the disembodied personality, which has used the other as a substitution for its own interior life, and is now forced, quite suddenly, to encounter these dimensions within.

One is tempted to venture a Bakhtinian reading of Arkady's predicament on the Neva - his lonely disembodied existence in the wake of Vasya's demiseas a natural consequence of the dialogical nature of selfhood. In Bakhtinian terms, Arkady's bereft status as I-for-myself, his sensation of ghostly semiexistence or soul-lessness could be read as a result of the "dialogical need for the other." Since the fullness of being exists only within human relationships, Vasya, as a beloved other, acted as "bestower" of "soul" upon Arkady. ${ }^{16}$ In Vasya's

16 Bakhtin, "Author and Hero in Aesthetic Activity," in Art and Answerability: Early Philosophical Essays by M. M. Bakhtin, ed. Michael Holquist and Vadim Liapunov, trans. Vadim Liapunov (Austin: University of Texas Press, 1990): 101. In Gerald Pirog's words, "It is in this sense that we can speak of our absolute aesthetic need for the other, who alone can 
absence, the lonely consciousness is reduced to a "spurious and disjected subjectivity" that can have no soul on its own. ${ }^{17}$ Such an argument, however, would dramatically contradict the tenets of Bakhtin's thought, since Bakhtin, who tended not to see the darker aspects of dialogue in Dostoevsky, ${ }^{18}$ insisted that dialogical interaction takes place between "unmerged" and "sovereign" consciousnesses. ${ }^{19}$ These sudden interior sensations (the surges of blood from an unknown source) that emerge in the absence of the external soul indicate that there is another level of complexity underlying Arkady's radical solitude - that his need to enact his personality intersubjectively is the result of pathologically suppressed or erased interior life. Dostoevsky's return to this relationship in Crime and Punishment, as we shall see, points to the collapse of the intersubjective self as a moment of central and sustained importance in his thought.

\section{Fear of the Interior}

For good reasons, Raskolnikov's lineage is most often traced to the radical idealists of Dostoevsky's earlier prose, the "dreamers" who long to "transform the world and bring it into conformity with [their] visionary longings," and the intellectual rebels, from Golyadkin to the Underground Man, who attempt to

create my completed personality. This personality would not exist if the other did not create it.... We are ... in a constant state of complementarity with others, who must also seek in us their own completed selves"; Pirog, "Bakhtin and Freud on the Ego," in Russian Literature and Psychoanalysis, ed. Daniel Rancour-Laferriere (Amsterdam: John Benjamins, 1988), 407-8.

17 Bakhtin, "Author and Hero in Aesthetic Activity," 101.

18 "Remarkably," observes Caryl Emerson, "Bakhtin assumes that the other's finalizing efforts are always benign —or at least a given self is presumed resilient enough to incorporate, or counter, any definition the other might thrust upon it"; Emerson, "Russian Orthodoxy and the Early Bakhtin," Religion \& Literature 22, nos. 2-3 (1990): 116. Sasha Spektor argues that dialogue in Dostoevsky is "the site of an intense struggle for authorial power," a struggle fueled by characters' "metaphysical anxiety" concerning the absence of a divine author; Spektor, "From Violence to Silence: Vicissitudes of Reading (in) The Idiot," Slavic Review 72, no. 3 (Fall 2013): 557. For an extensive examination of the difference between the ideal of harmonious intersubjectivity and the "abyss ... where polyphony threatens to become cacophony," see Jones, Dostoevsky after Bakhtin, xiv. For an authoritative look at some of the most persuasive challenges mounted against Bakhtin's theory of polyphony and dialogue with regard to Dostoevsky, see Caryl Emerson, The First Hundred Years of Mikhail Bakhtin (Princeton, NJ: Princeton University Press, 1997), esp. 130-49.

19 Bakhtin, Problems of Dostoevsky's Poetics, 26. On this aspect of Bakhtin's thought, see especially Alina Wyman, "Bakhtin and Scheler: Toward a Theory of Active Understanding," Slavic and East European Review 86, no. 1 (2008): 58-89. 
stage a "revolt against the established social-moral order." ${ }^{20}$ Innumerable analyses of Raskolnikov's internal divisions have refined for us his image as an exacerbated intellect, testing out the postulates of ideological theories while hindered by his inescapable status as a "trembling creature" subject to natural laws and impulses. ${ }^{21}$ Raskolnikov's connection with Vasya Shumkov, however, opens up a markedly different aspect of his character: through this lens we see Raskolnikov as a weak, damaged, and incomplete personality who attempts hysterically to escape domination by external administrative minds. A brief examination of some of the resonances between Crime and Punishment and the early, little-studied story helps us further grasp the tension between interiority and intersubjectivity that underlies both texts and that helps define the problem of selfhood in Dostoevsky.

The first, most apparent repetition from the earlier template lies in the description of Raskolnikov and Razumikhin's friendship. When in Raskolnikov's presence, Razumikhin reminds us distinctly of Arkady in his struggle to annex and take over his friend's functioning; his "powerful arms" (PSS, 6:150), like Arkady's (2:33), grasp hold of Raskolnikov and forcefully direct him toward health, prudence, and recuperation. Razumikhin's surname (formed from razum, "reason") takes on a much more literal meaning in this context since, like Arkady, he enacts the faculty of the executive mind externally for the incomplete self. ${ }^{22}$ We see him "taking charge at once," deftly "grasping” Raskolnikov's "head with his left hand, regardless of the fact that [Raskolnikov] would have been able to get up himself," and bringing soup and tea to the latter's lips (6:95). He immediately takes over Raskolnikov's finances and personal appearance, buying clothes for his helpless counterpart, and he even overcomes indignant opposition ("Leave me be! I don't want it!") in changing Raskolnikov's

20 Joseph Frank, Dostoevsky: The Miraculous Years, 1865-1871 (Princeton, NJ: Princeton University Press, 1995), 98-99.

21 See, for example, Richard Peace's foundational reading of Raskolnikov as "above all else, a man whose actions are based on cool and calculating reason”; Peace, Dostoevsky: An Examination of the Major Novels (Cambridge: Cambridge University Press, 1971), 19.

22 Marina Kostalevsky describes Razumikhin as "the positive personification of rational good"; Kostalevsky, Dostoevsky and Soloviev (New Haven, CT: Yale University Press, 1997), 154. Frank, who notes the similarity between Arkady and Razumikhin, suggests that his surname “indicates Dostoevsky's desire to link the employment of this faculty not only with the cold calculations of utilitarianism but also with spontaneous human warmth and generosity" (Dostoevsky, 99). 
undergarments, while the latter, defeated and humiliated, eventually complies (6:101-2). The struggle of wills concerning the problem of signature (the desire to annex the identity of the other) is repeated from the earlier story. When Raskolnikov refuses to sign for his mother's gift of money, Razumikhin attests to his ability to "direct" the invalid ("we will direct him, that is, simply guide his hand"), and, we are told, "was seriously getting ready to guide Raskolnikov's hand," before Raskolnikov, like Vasya, insists on signing himself (6:94).

In "A Weak Heart," we follow Arkady's agony closely as he gradually loses all control over his counterpart; in the later novel, the entire emphasis is upon the fugitive self, Raskolnikov, protecting an interior personal realm in which is concealed, among other, more deeply buried memories, a recent crime. As Raskolnikov attempts to escape Razumikhin's vigilant surveillance, he, like Vasya, has no defined intention of his own-only a suppressed sense of agency that fuels disorganized, frenzied activity. In the absence of external surveillance, he is unable to stay in his room and sleep, unable to fulfill the sensible command of his external superego, but he "leaps up, half crazed from the bed" as soon as he is left alone "with burning convulsive impatience" to do something (PSS, 6:99). The descriptions of Raskolnikov released from Razumikhin's supervision emphasize simultaneously a desperate desire to exert agency and an utter incapacity for thought or self-administration: "He didn't know and didn't think about where to go; he knew one thing: 'that it was necessary to end all this today, in one go, at once...' How to end it? With what? About this he didn't have any idea, and he didn't want to think" (6:21). Raskolnikov's subsequent hysterical bustling about the city directly repeats Vasya's. When Arkady leaves, Vasya simply cannot stay at home, for all the good it would do him. Instead, he feels a frantic compulsion to go directly to the authorities, to confess his "crime," though he can give no rational explanation for his impulse. Arkady's desperate, agonized search for Vasya, who has run away from his incarceration in their room, is replayed in the novel, as the friends collide suddenly, like Arkady and Vasya, on the street- "Neither had caught sight of the other up to the last step, so that they almost collided heads" (6:129) —and Razumikhin scolds his disobedient friend-"I'm going to take you up under my arm, ... and carry you home, then lock you in!” (6:129)—implying a real sense of ownership over him. 
In Crime and Punishment, the pathology of the shared personality is still more pronounced than in "A Weak Heart." For all of Raskolnikov's attempts to evade Razumikhin, we see that he exhibits a desperate need for his friend as a result of his own incapacity for self-administration. From the beginning, despite himself, he is deeply, actively embroiled in the shared self that his friendship with Razumikhin enacts. Upon receiving the devastating news of his sister's intended marriage, he seeks out Razumikhin compulsively, in a state of despair, as if hypnotized, crying out for his friend's surveillance, though unaware of it himself:

"And where am I going?" he thought suddenly.... The question, why had he now set off to see Razumikhin bothered him more than it even seemed to him; ... "Could I really have wanted to fix the whole business through Razumikhin alone and find the solution to everything in Razumikhin," he asked himself in surprise. (PSS, 6:43-45)

The murder is committed in that moment when Raskolnikov, panicked and distraught, overcomes his mysterious compulsion to visit Razumikhin, and attempts to assume responsibility himself for his family dilemma. The crime is committed outside of Razumikhin's purview, as an expression of Raskolnikov's own hysterical attempt at personal agency. We discover later in the novel that Raskolnikov cannot survive for long without an external mind-when he finally shirks Razumikhin's supervision, he immediately binds himself to other kinds of external minds and agencies, most prominently to those of Svidrigailov and Sonya. In this sense, the novel comes to explore not only the collapsed interior life of the incomplete personality but also the ways in which this atrophied self succumbs to various external sources of intellection.

The image of pretend sleep as a symbol of concealed interiority (or of the collective self's instability) finds immense resonance in the novel. Vasya's pretend sleep in Arkady's dream, as examined above, dramatized the externalized relationship of the prostrate, malleable body to the executive mind: the subdued being feigns docility while hiding a secret, interior life, planning its escape and bid for independent agency. Pretending to be a compliant limb of Razumikhin's administrative will, Raskolnikov, like Vasya, "conceals his power" from his friend with a "feral cunning" (PSS, 6:95-96), "closing his eyes and pretending to be asleep" as he hears Razumikhin entering the room 
(6:210). As Raskolnikov transfers to the administration of Svidrigailov, the nature of their relationship is quickly established (as if by shorthand) by use of this image $(6: 214,219)$. Later, we discover that Svidrigailov (who incidentally has the same name and patronymic-Arkady Ivanovich-as Vasya Shumkov's friend and mentor) comes to suicidal despair after his dream in which he is confronted by the image-"horrific" to him-of a child, pretending to sleep, concealing depravity and mockery under closed eyelids: "Her long dark eyelashes seem to shiver and wink, and from under them looks out a sly, sharp, unchildlike-winking little eye, as if the little girl is not sleeping and is pretending." When the child's eyes finally open, we infer from Svidrigailov's acute terror that he sees something from his own muchavoided unconscious realm in the "boundlessly ugly and offensive ... filth" that no longer conceals itself under the winking eyelids. In each of these instances, the unconscious interior life - that which is hidden behind closed eyelids - is a region of shame, ugliness, disgust, the unwanted memory of a violent crime or a case full of neglected notebooks. It is the shame over and avoidance of what is hidden beneath the veneer of this pretend sleep that propels the personality beyond the threshold of the self into a world of frantic intersubjective activity. In each case these hateful interior phenomena are placed outside of the self, into another person, until that other person refuses to be subsumed, awakens covertly from an enforced sleep, and launches a rebellion against the colonizing other.

\section{Some Conclusions}

The intersecting personalities of Vasya and Arkady testify to the brokenness of dialogic interaction in early Dostoevsky and to the pathologies inherent in his conception of the open-ended, relational self. Whether we prefer a diagnosis of "morbid codependency" or "projective identification," 23 or whether we suspect subliminal sexual anxieties or repressed desires in Arkady and Vasya, it is clear that Dostoevsky is describing disturbed characters who suffer from some form of collapsed interiority, and that the deficiency of the interior dimension causes them to cling to each other with greater convulsive energy. Even Razumikhin,

23 "Morbid codependency" in early Dostoevsky is examined by Thomas G. Marullo, Heroine Abuse: The Poetics of Codependency in "Netochka Nezvanova" (DeKalb, IL: Northern Illinois University Press, 2016). 
the most refreshingly level-headed of Dostoevsky's characters, nevertheless exhibits all the hungry embraces of a disturbed psyche. Though Pulkheria Alexandrovna and Dunya do not "want to notice these eccentric details," still he grasps onto their hands "as if in a vise," pressing them "to the point of pain," grasping them "even more firmly" if they attempt to "tear their hands away" as they realize that it is "impossible to run away from him" (PSS, 6:154). In the context of these ravenous, colonizing personalities, both the early story and the later novel approach the question of introspection-of stepping back from the compulsive threshold through the discovery and acknowledgment of what is concealed within: whether in Vasya's passionate desire to confess his "crime" to Yulian Mastakovich, or in Raskolnikov's to confess his murder and to atone for it. Both crimes, though obviously different in their degree of seriousness, can be understood as metaphors for the recognition of interior, personal space, especially since the crimes themselves, we suspect, point to the presence of earlier, more deeply buried memories in these characters whose personal biographies and "former past," rarely mentioned, are glimpsed, if at all, from afar, in the waters of the Neva, "in some depths, below, somewhere barely visible" (6:90).

Vasya Shumkov's interior awakening sheds some light on the tension between interiority and intersubjectivity in Dostoevsky, since it suggests that if the self is simply the site of consciousness, a point of view, or an activity of addressivity directed toward the other, then the gulf between selves cannot be preserved: the self falls into and becomes subsumed into the other. As Ivan's formulation goes in Brothers Karamazov, "If there is no immortality of the soul, then all is permitted, even anthropophagy" (PSS, 14:65). The example that occurs to Ivan — anthropophagy — is significant, and his idea could be rephrased thus: without the positing of an essential interior principle within the self, human beings will consume each other. In early Dostoevsky, we are left simply with a depiction of the need to recover an interior essential space in the self as a psychological quandary, but one which takes us back with renewed attention to Dostoevsky's novelistic examinations of the reconstitution of the interior realm from its dispersal into adjacent, convulsively embracing selves. 
